Volume 8

$12-29-2021$

\title{
Liberalism, Patriotism, and Cosmopolitanism in Local Citizenship in a Global Age
}

Eric R. Claeys

George Mason University School of Law, eric.claeys@gmail.com

Follow this and additional works at: https://scholarship.law.tamu.edu/journal-of-property-law

Part of the Law and Society Commons, Property Law and Real Estate Commons, and the Public Law and Legal Theory Commons

\section{Recommended Citation}

Eric R. Claeys, Liberalism, Patriotism, and Cosmopolitanism in Local Citizenship in a Global Age, 8 Tex. A\&M J. Prop. L. 1 (2021).

Available at: https://doi.org/10.37419/JPL.V8.I1.1

This Symposia Article is brought to you for free and open access by Texas A\&M Law Scholarship. It has been accepted for inclusion in Texas A\&M Journal of Property Law by an authorized editor of Texas A\&M Law Scholarship. For more information, please contact aretteen@law.tamu.edu. 


\title{
Liberalism, PaTriotism, AND COSMOPOLITANISM IN LoCaL CITIZENSHIP IN A GLOBAL AGE
}

\author{
Eric R. Claeys"
}

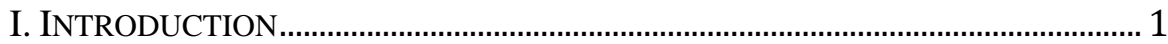

II. THE ARGUMENT OF LOCAL CITIZENSHIP IN A GLOBAL AGE ....................... 4

III. ASSESSING LOCAL CITIZENSHIP IN A GLOBAL AGE ……………………….... 6

IV. IMMIGRATION, CITIZENSHIP, AND COSMOPOLITANISM................................. 8

V. NATURAL RIGHTS, COSMOPOLITANISM, AND PATRIOTISM …………........11

VI. COOPTING PATRIOTISM FOR LIBERALISM AND NATURAL RIGHTS .........12

VII. RECONSIDERING LOCAL CITIZENSHIP IN A GLOBAL AGE..........................15

\section{INTRODUCTION}

Immigration and citizenship are both fraught areas of policy. The federal government has long exercised broad authority over immigration and the status of aliens; that authority is often tested by states. ${ }^{1}$ And immigration and citizenship both raise difficult trade-offs. Americans live in a country dedicated to the proposition that "all men are created equal" and entitled to "unalienable" rights. ${ }^{2}$ That proposition seems to favor relatively welcoming immigration policies and relatively easy paths to state and national citizenship. But our founding documents also take for granted that we constitute "one people," ${ }^{3}$ and on that basis general commitments to human equality and freedom may need to be reconciled with considerations that limit access to the United States and United States citizenship.

In his recent book Local Citizenship in a Global Age, ${ }^{4}$ Kenneth Stahl studies a slice of immigration and citizenship policy. The book focuses on the efforts of a few cities in the United States to chart their own courses on topics associated with immigration and citizenship. The book has two main claims. First, the United States "practice[s]

DOI: https://doi.org/10.37419/JPL.V8.I1.1

'Professor, Antonin Scalia Law School, George Mason University.

1. See, e.g., Arizona v. United States, 567 U.S. 387 (2012).

2. THE DECLARATION OF INDEPENDENCE para. 2 (U.S. 1776).

3. $I d$.

4. Kenneth A. Stahl, Local Citizenship in a Global Age (forthcoming). 
'citizenship federalism"”; "citizenship" gets "distributed at multiple scales" of government "simultaneously, and often on divergent grounds." ${ }^{5}$ Second, today, when governments disagree with each other about immigration and citizenship policy, the disputants are usually local governments on one hand and the federal government on the other. "Today, "states play[] a passive role" in debates over immigration and citizenship policy, while "local and federal governments tend to distribute citizenship in ways that are . . . in direct contradiction." 7

To describe the different views that lead governments to disagree about immigration and citizenship, Local Citizenship in a Global Age introduces many different models of citizenship. It argues that three models have dominated to this point. One is a "republican" model, which expects citizens to "exercise [their] judgment to the best interest of the [community] without regard to [their] own personal financial or familial interest." In the "liberal" model, citizenship is not so much "a set of civic responsibilities" as a status; it entails "the right of an individual to own private property and safeguard it." Since citizenship does not entail many responsibilities in the liberal model, that model can "be extended far and wide." In contrast with both the republican and the liberal models, "the ethno-nationalist [model] considers citizenship a device for linking a group of people together under the banner of a shared culture or identity." Local Citizenship in a Global Age also introduces two models for municipal governments to institute going forward - models of postmodern and differentiated citizenship, both of which delink citizenship in a municipality from citizenship in that municipality's state and country. ${ }^{11}$

Local Citizenship in a Global Age is an enriching book. It calls attention to some important developments in local government, citizenship, and immigration policy. It conveys wonderfully how messy the law and politics are around immigration and citizenship. And the book is imaginative when it makes recommendations about immigration and citizenship policy at the municipal level.

In this review Essay, I survey the most valuable lessons from Local Citizenship in a Global Age. But I have some reservations about

\footnotetext{
5. Id. at 4 .

6. $I d$.

7. $I d$.

8. Id. at 21 .

9. Id. at 24 .

10. Id. at 26 .

11. See id. at 191-224.
} 
the book, and I want to mark those off as well. The book comes off as critical of views that seek to control immigration and to establish relatively demanding criteria for noncitizens to become citizens. In my view, two factors contribute to this impression, and the book would have been more satisfying if both had been addressed.

First, Local Citizenship in a Global Age does not account for a phenomenon I call here "cosmopolitanism." 12 The book focuses a great deal on the possibility that opponents oppose open immigration and easy citizenship because they are too attached to race or nationality-hence the ethno-nationalist model of citizenship. ${ }^{13}$ But people can also be detached from their own communities, and particularly from the habits and values that help constitute community life and make it satisfying. Sometimes that detachment is appropriate, sometimes it is not, and in either case the tendency needs to be studied. That tendency is called "cosmopolitan" in this Essay. I suspect that cosmopolitanism plays a role in the events and policies studied in Local Citizenship in a Global Age. I also suspect that cosmopolitanism shapes policy conflicts as much as Stahl's "liberal," "republican," and "ethno-nationalist" models.

Second, Local Citizenship in a Global Age does not portray in their most favorable light the concerns that lead some citizens to oppose high-volume immigration and easy paths to citizenship. The book suggests that policies that oppose open immigration and easy citizenship cannot be grounded in liberal views. ${ }^{14}$ Again, the book assumes there are three main models of citizenship-liberal, republican, and ethno-nationalist. ${ }^{15}$ It seems easy to justify policies that oppose open immigration and easy citizenship on grounds that seem (to lay people) communitarian or (in Stahl's presentation) republican. It also seems easy to associate those policies with ethnonationalist desires, though those associations come nowhere close to a defense. But those policies seem impossible to square with liberal tenets about government, freedom, and justice. Yet many political and thought leaders have assumed that a program for government can at once be liberal and patriotic - supportive of country, one's people, and

12. Martha C. Nussbaum, Patriotism and Cosmopolitanism, Bos. REV. (Oct. 1, 1994), http://bostonreview.net/martha-nussbaum-patriotism-and-cosmopolitanism [https://perma.cc/4V6H-TYQF]. Nussbaum made this contrast popular, and I follow her usage here. Nussbaum later expanded her thoughts on both in MARTHA C. Nussbaum, THE COSMOPOLITAN TRADITION: A NOBLE But FlAWEd IdEAL (2019).

13. See STAHL, supra note 4, at 102.

14. Id. at $59-60$.

15. Id. at 21 . 
one's way of life. I want to sketch an account of patriotic liberal theories and explain the implications for the argument in Local Citizenship in a Global Age.

This Essay's argument proceeds as follows. Part II restates the argument of Local Citizenship in a Global Age. Part III surveys the book's strengths and highlights my main concerns. Part III identifies the void in the book that cosmopolitanism would fill, and Part IV discusses the psychological tendencies that contribute to the cosmopolitan mindset. Part V explains why liberal theories of government can incorporate patriotic elements, and Part VI outlines the main concerns that animate patriotic liberal theories. Part VII explains the implications that Parts III through VI have for Local Citizenship in a Global Age.

\section{The Argument of Local Citizenship in a Global Age}

Local Citizenship in a Global Age proceeds in three parts. Part I supplies the background readers will need to follow the rest of the book's argument. Chapter 1 introduces the three models of citizenship-liberal, republican, and ethno-nationalist. Chapter 2 shows how citizenship is regulated by different levels of government in the American federal system. Many assume that central governments reserve plenary authority to grant or withhold citizenship. Nevertheless, in practice, the federal government "determine[s] who qualifies as a citizen based on characteristics such as identity or demonstrated loyalty," while local governments make de facto determinations who count as citizens by deciding whom to give advantages like public benefits, public services, and protection from land-use regulations. ${ }^{16}$ Chapter 3 supplies a quick overview of local citizenship in the ancient world ... and the transition in the Western world from small city-states with republican citizens to extended nation-states with less demanding expectations of citizenship. ${ }^{17}$

Part II presents three case studies of local citizenship in action. Chapter 4 studies how United States municipalities and (later) states enfranchised women before the Nineteenth Amendment. ${ }^{18}$ A few American municipalities have extended perquisites of citizenship to noncitizen residents, and Chapter 5 studies these extensions- to the

16. Id. at 40 ; see id. at 41 .

17. See id. at 69-81.

18. U.S. CONST. amend. XIX; see id. at 85-95. 
franchise, to access to health care and local banking institutions, or to equal access to benefits of state citizenship like public education, tuition discounts, and state-supported health care. ${ }^{19}$ Some municipalities extend perquisites of citizenship to nonresident landowners, and Chapter 6 studies those extensions. ${ }^{20}$ When Stahl interprets all of these developments, he relies on the three models of citizenship introduced in Chapter 1 . When federal authorities made and administered national citizenship policies, they focused on concerns that loom large in republican or ethno-nationalist models. Because local citizenship is so far removed from national citizenship, Stahl argues, they could focus on the concerns that justify the liberal model. ${ }^{21}$ But politics have gotten more complicated in the last 50 years because of globalization. Because "globalization is destabilizing" existing political orders and distinctions, "the distinction between local and federal citizenship is breaking down." "22 "[T]he liberal conception of citizenship that prevails at the local level has bled into the federal level," and that bleeding has "unsettl[ed] the ethnonationalist and republican conceptions thought to be safely enshrined there." ${ }^{23}$ Chapter 7 demonstrates that claim.

Part III considers three alternative models of citizenship. Chapter 8 explains why it is necessary to consider alternatives: If the models studied in Part II are unraveling, then theorists and policymakers need new models to replace the unraveling ones. Chapter 9 studies one possible source for such a model: neo-republican theories of citizenship. But Stahl finds neo-republicanism wanting; he argues that municipalities are expanding their franchises and offering public benefits to a wide range of noncitizens in "direct response to the failures of nation-state citizenship." 24 Chapter 10 considers postmodern citizenship, in which "citizenship consists largely of accommodating oneself to the wide diversity and difference of urban life." ${ }^{25}$ But Chapter 10 also offers a sober warning about postmodern citizenship. Because this conception "refus[es] to draw any boundaries

19. See STAHL, supra note 4 , at 97.

20. See id. at $124-40$.

21. See id. at 92-93, 103, 127.

22. Id. at 142 .

23. $I d$.

24. Id. at 175 (citing and criticizing Michael WALZER, SPHERES OF JUSTICE, 38-39 (1983)).

25. Id. at 192 (citing GERALD FRUG, CitY MAKING: BuILDING COMMUNITIES Without BuILding Walls (1999); Gerald E. Frug, City Services, 73 N.Y.U. L. REV. 23 (1998)). 
around places at all" in public life, it may - however unintentionallyencourage residents to "flee to neighboring suburban communities where they can exercise more control over their environments." 26 Chapter 11 offers what Stahl portrays as a compromise between neorepublican and postmodern models-"differentiated citizenship." 27 Differentiated citizenship encourages people to develop political relationships not directly between themselves and the state but instead through the media of "cultural group[s]"- - "different national, ethnic, or religious groups to which they belong" — "intermediate between the individual and the state." 28

\section{Assessing Local Citizenship In a Global AGE}

Local Citizenship in a Global Age is an enriching book. It tackles several of the most pressing topics in politics today. As Stahl observes, Donald Trump became President of the United States in large part because he voiced concerns about American foreign and citizenship policy that few conventional politicians had been willing to raise. ${ }^{29}$ The same questions have roiled politics in Europe; they contributed to the five years of turmoil that the United Kingdom went through before it withdrew from the European Union. ${ }^{30}$

Stahl offers many fine insights on these topics. Chapters 5 and 6 in particular contribute significantly to legal and political science scholarship on citizenship policy. Chapter 5 provides an invaluable report on the efforts of states and municipalities in the United States to extend to people who are not U.S. citizens voting rights and benefits that often run with citizenship. Chapter 6 fills an important gap when it recounts changes by municipal governments to extend the franchise to nonresident landowners.

Local Citizenship in a Global Age also provides a helpful primer about municipal and state citizenship policy in a global age. As I explain below, Stahl and I probably disagree whether the trends he describes in his book can or should be reversed. But if one grants that globalization is hard to reverse, Chapters 9, 10, and 11 help mark off

26. Id. at $208,204$.

27. Id. at 208 (crediting Will KyMlicka, Multicultural CitizenshiP (1995); IRIS MARION YOUNG, JUSTICE AND THE POLITICS OF DIFFERENCE (1990)).

28. Id. at 208-09.

29. See id. at $1-5$.

30. See, e.g., James McBride, What Brexit Means, CouncIL ON ForeIGN Rel.: BACKGROUNDERS (last updated July 22, 2019 8:00 AM), https://www.cfr.org/backgrounder/what-brexit-means [https://perma.cc/9AW4BH83]. 
the choices that policy makers must make. Republican citizenship, postmodern citizenship, and differentiated citizenship present different models of citizenship, and those models should help readers appreciate what local citizenship might entail in an age in which globalization seems to be weakening people's attachments to their political communities.

Which takes me to the last enriching feature of Local Citizenship in a Global Age: The book makes readers think hard about citizenship and political allegiance. Someone who lives in Takoma Park is at once a resident of a municipality, a state (Maryland), a nation-state (the United States), and in some sense the world. The first three jurisdictions have some claims on that person's allegiance, and maybe the world does now, too. Does every one of those jurisdictions need to march in lockstep with the others when it sets policy about citizenship? Clearly not, and Local Citizenship in a Global Age convinces me as much. How should citizenship be structured? At its core, citizenship consists of a status and the right to vote in a jurisdiction's elections. Does it also entail rights of access to public assistance services? Rights of access to education? Rights to be free from investigation and possible deportation by other sovereigns? How do we classify people to whom a municipality extends some of these advantages but not all? I had not considered issues like these before reading Local Citizenship in a Global Age, and I am grateful to Stahl for forcing me to think them through.

Even so, I am not persuaded by the main argument in Local Citizenship in a Global Age. I favor immigration and citizenship policies that combine what Stahl calls liberal and republican elements-a mix that I call "natural rights republicanism." ${ }^{31}$ In my opinion, a just political community should be at once (in Stahl's formulation) liberal and republican. Such a community should be liberal in "its dedication to equality and natural rights," but it should be republican in maintaining "public morals . . inculcat[ing] respect for equality and natural rights." 32 Probably because I find natural

31. Eric R. Claeys, Review of Thomas G. West, The Political Theory of the American Founding: Natural Rights, Public Policy, and the Moral Conditions of Freedom, 44 INTERPRETATION 319, 319 (2018).

32. Id. at 321-22; see also Eric R. Claeys, The Private Society and the Liberal Public Good in John Locke's Thought, 25 SOC. PHIL. \& POL'Y 201 (2008) (interpreting JOHN LOCKE, A LETTER CONCERNING TOLERATION (Rob Hay ed., McMaster University Archive of the History of Economic Thought 2004) and JOHN LOCKE, Two Treatises of Government (Peter Laslett ed., Cambridge Univ. Press 1988) (1690)). 
rights republicanism satisfying, I am more interested in studying citizenship at the state and national levels (pace Stahl) and less so in studying it at the municipal and global levels. In my opinion, the weakening of state and national citizenship could have been arrested more than is assumed in Part II of Local Citizenship in a Global Age.

It should come as no surprise, then, that I have two broad concerns about Local Citizenship in a Global Age. I worry that the book does not account adequately for some of the forces that have destabilized state and national citizenship. I also worry that the book does not portray charitably enough views that might justify policies limiting immigration and setting demanding criteria for citizenship. The first concern is taken up in the next two Parts of this Essay, and the second concern is discussed in Parts V and VI.

\section{IMMIGRATION, CITIZENSHIP, AND COSMOPOLITANISM}

Let me start with my concern about the forces that question the primacy that state and national governments have traditionally exercised over immigration and citizenship policy. Stahl's three-part taxonomy seems to be missing a possibility. Again, Local Citizenship in a Global Age introduces three models of citizenship-liberal, republican, and ethno-nationalist. ${ }^{33}$ The liberal and republican models are obviously normative models. As Stahl portrays them, "liberal" arguments always militate in favor of strong individual rights, and they deny communities authority to withhold laws protecting those rights. ${ }^{34}$ "Republican" arguments always militate in favor of strong communities - a strong sense of "public" — and relatively closed communities at that. ${ }^{35}$ The ethno-nationalist model, by contrast, is not normative. The traits that move people to be loyal to race or country are facts about human nature; they describe psychological forces that structure human sociability. ${ }^{36}$ These forces can be coopted toward goals both good and bad but are themselves morally neutral.

In short, Local Citizenship in a Global Age introduces both normative and psychological models, and those models cut in different directions in citizenship and immigration policy. To appreciate how the models relate to each other and to relevant theory, we can arrange them in a table:

33. See STAHL, supra note 4 , at 21 .

34. Id. at 32 .

35. Id.

36. $I d$. at 26. 
Table 1. Models of citizenship ${ }^{37}$

\begin{tabular}{|l|l|l|}
\hline Policy & $\begin{array}{l}\text { For restricting } \\
\text { immigration (and, for } \\
\text { making citizenship } \\
\text { difficult to earn) }\end{array}$ & $\begin{array}{l}\text { For opening } \\
\text { immigration (and, for } \\
\text { making citizenship easy } \\
\text { to earn) }\end{array}$ \\
\hline Normative & Republican & Liberal \\
\hline Psychological & Ethno-nationalist & $?$ \\
\hline
\end{tabular}

As Table 1 helps show, something seems missing. Ethnonationalism covers the psychological forces that might lead people to favor keeping their political communities relatively closed, restricting immigration, and restricting access to citizenship only to people who resemble existing citizens relatively closely. ${ }^{38}$ As Local Citizenship in a Global Age suggests, however, for a couple of generations, these forces have been losing ground. ${ }^{39}$ So it seems reasonable to ask whether the passions that lead people to embrace ethno-nationalist views are getting confronted and even overridden by other opposing passions.

I can think of such a cluster of passions. The passions in this cluster have been described in a few different ways. The most sympathetic descriptive term is "cosmopolitan." Cosmopolitans find connections that people have besides their national identities more ennobling than connections tied to those identities. ${ }^{40}$ As Martha Nussbaum portrays things, politics can be based on three different elements: "ethnic and racial and religious difference," "shared national identity," and "[w]hat we share as rational and mutually dependent human beings." 41 Cosmopolitans believe that the third element takes priority over the first two: People are not "above all citizens of the United States" or any other country but instead "above all citizens of a world of human beings." "42 The best-known unsympathetic descriptor is "oikophobic." "Oikophobia" is a neologism developed by Roger Scruton. It plays on another neologism, the word "xenophobia," which conjoins the Greek words

37. Id. at 38-39.

38. Id. at $27-28$.

39. Id. at 21 .

40. Martha C. Nussbaum, Patriotism and Cosmopolitanism, Bos. REV. (Oct. 1, 1994), http://bostonreview.net/martha-nussbaum-patriotism-and-cosmopolitanism [https://perma.cc/4V6H-TYQF].

41. Id.

42. Id. 
xenos (stranger, or foreigner) and phobia (fear). 43 "Oikophobic" switches out xenos and inserts instead the Greek word oikos, for "home." 44 Scruton argues that oikophobia fairly describes tendencies that motivate intellectuals, particularly intellectuals in a society with a mass culture. ${ }^{45}$ Intellectuals tend to find more in common with intellectuals from other cultures than they find with non-intellectuals from their own cultures. In addition, because intellectuals like to manipulate ideas, they dislike being tied to existing ways of doing things and existing orders. ${ }^{46}$ Many intellectuals "see[] that which is [their] own, [their] inheritance, as alien," Scruton argues, and they feel "tainted by its claim on [them]." 47 In response, intellectuals often "portray [their] home as something Other, by means of a stereotype that seems to free [them] from all obligation toward it," and they tend to see "other cultures" and people of those cultures "through a sentimental haze." 48

Scruton describes accurately many of the passions that motivate intellectuals. When it comes to choosing terms to describe those motivations, however, I will follow Nussbaum and not Scruton. In part, I do so for reasons of charity. Like "xenophobic," "oikophobic" does not seem a term appropriate to civil discourse about a fraught topic. ${ }^{49}$ And in part, I do so to make the term I use to describe people who mistrust closed communities track its opposite, "ethnonationalist." Like ethno-nationalist political passions, cosmopolitan passions can be coopted in good and bad causes. Some people want to improve the lots of individual peoples and social groups, and they earnestly believe that local practices and lifestyles hold those people and groups back. In some contexts, those motivations can make people's lives better. In the wrong contexts, however, those same motivations can backfire. Cosmopolitan policies can be wellintentioned and yet destabilize local social institutions that mutually dependent beings need to prosper. The policies that Stahl describes as republican can be reinforced, for better or worse, by social passions he

43. The History of the Word 'Xenophobia,' MERRIAM WEBSTER, https://www.merriam-webster.com/words-at-play/a-short-history-of-xenophobia [https://perma.cc/NW4N-XSAB] (last visited Mar. 22, 2021).

44. Roger Scruton, Oikophobia, 175 J. EDUC. 93, 96 (1993).

45. Id. at 96 .

46. See id.

47. Id.

48. Id. at 97 .

49. The term "xenophobic" detracts from the argument when used in Local Citizenship in a Global Age. See STAHL, supra note 4, at 17, 176, 191, 207. 
describes as ethno-nationalist. By the same token, policies he describes as liberal can be reinforced, for better or worse, by sentiments and social passions that might fairly be called cosmopolitan. The argument of Local Citizenship in a Global Age seems incomplete without an account of those latter sentiments and passions.

\section{NATURAL RIGHTS, COSMOPOLITANISM, AND PATRIOTISM}

In Part III, I warned that Local Citizenship in a Global Age may not portray charitably enough views that might justify restricting immigration and setting demanding criteria for noncitizens to become citizens. I want to come back to that warning here. To illustrate my concern, I will study the ways in which the book uses the term "liberal" and the phrase "natural rights." As used in Local Citizenship in a Global Age, these terms always support policies for open political communities and easy-to-satisfy citizenship tests. But these terms can also be used to support policies that make national and local citizenship respectable. In other words, not every political program that is liberal and devoted to natural rights is cosmopolitan; some such programs justify what might be called "patriotic" commitments.

As portrayed in Local Citizenship in a Global Age, "liberalism asserts that all human beings have natural rights," and "liberal citizenship should in principle be available to all regardless of nationality. " suggest that Stahl is using "liberal" or "natural rights" in misleading or idiosyncratic senses. "Liberal" and "natural rights" can take on different meanings in different contexts. On one hand, "liberal" and "natural rights" are both theoretical concepts. When theoretical concepts are introduced and defended in theoretical discussions, they can be justified carefully with qualifications to alleviate any extreme tendencies they have. On the other hand, "liberal" and "natural rights" can also be applied straightaway to political life. In the rough and tumble of political life, they tend to be applied as slogans with few or no qualifications. Local Citizenship in a Global Age assumes that "liberal" and "natural rights" have the meanings they have in slogan portraits and in libertarian political theories. But other political theories appeal to natural rights and liberalism at a fundamental level

50. Id. at 29. Although Stahl speaks specifically of Lockean liberalism, this passage explains how he relies on his so-called "liberal" model throughout the rest of the book. 
to justify many practical policies that laypeople would associate with love of one's own country. Again, I have associated such theories with "natural rights republicanism." But one could just as plausibly call such theories "patriotic liberal" theories, and that is the phrase I use here.

\section{COOPTING PATRIOTISM FOR LIBERALISM AND NATURAL RIGHTS}

Patriotic liberal theories should not seem outlandish or farfetched. Although the United States Declaration of Independence is dedicated (again) to natural rights and equality, it is a declaration for "one people" resolved "to dissolve the political bands which have connected them with another" and set "to assume [a] separate and equal station" as an independent nation. ${ }^{51}$ Although claims like these may sound paradoxical, they rest on reasonable and serious concerns. Consider how Nussbaum justifies cosmopolitan political projects: Such projects respect peoples' equal rights to develop their capacities as rational, mutually dependent beings. ${ }^{52}$ But what if it turns out that, precisely because people are mutually dependent beings, they need their social lives ordered? And what if social order hinges on people's agreeing to norms and goals that are common in their community but disputed by many other people? Thomas Jefferson, lead author of the Declaration, assumed that people needed to agree on basics of social and political life to be free: "It is for the happiness of those united in society to harmonize as much as possible in matters which they must of necessity transact together." 53

When liberal and natural rights theories require patriotic qualities, they rely on several reinforcing considerations. Four stand out. ${ }^{54}$

First, when citizens like their country and trust their fellow citizens, the affection and trust help secure individual rights. People cannot be secure in their natural rights unless fellow citizens respect them as bearers of natural rights. In principle, as a matter of prepolitical morality, all people are equally entitled to natural rights. Sadly, however, in practice, many people do not recognize or accept that claim. In many times and places, people have believed that they do not need to follow principles of justice when they transact with

51. THE DECLARATION OF INDEPENDENCE para. 2 (U.S. 1776).

52. See NUSSBAUM, supra note 12 , at 2.

53. Thomas JefFERSON, Notes on the State of Virginia, in THE Writings OF THOMAS JEFFERSON 120 (Albert Ellery Bergh ed., 1907).

54. ERIC R. Claeys, NATURAl Property Rights (forthcoming). The arguments in this Part are drawn from chapter 2 of the forthcoming book. 
people they classify as Others-people from another family, tribe, ethnicity, religious sect, or political faction. ${ }^{55}$ After the United States deposed Saddam Hussein, violence erupted in Iraq, and much of the violence has been motivated by mistrust among Iraqi Sunnis, Shiítes, and Kurds. ${ }^{56}$ In Federalist No. 2, John Jay was optimistic that the Constitution of 1787 would not lead the peoples of the several states into similar violence. But Jay was confident because he believed that state citizens were members of "one united people . . . descended from the same ancestors, speaking the same language, professing the same religion, attached to the same principles of government, [and] very similar in their manners and their customs." 57 Stahl cites this passage as an example of the ethno-nationalist model. ${ }^{58}$ But Jay made these observations in an argument that the Constitution of 1787 would secure the American people their natural rights more effectively than the Articles of Confederation were securing them. ${ }^{59}$

Second, patriotism can make people more secure in natural rights associated with personal safety and collective security. Sadly, nations and peoples may need to go to war to defend their citizens and possessions. Before a nation goes to war, it is reasonable for its people to expect all citizens to be loyal enough to the government and its projects to contribute to their defense. Stahl justly gives John Locke significant credit in ushering in political liberalism. ${ }^{60}$ Locke assumed that all commonwealths could and should "not permit[] any part of their Dominions to be dismemb[e]red, nor to be enjoyed by any but those of their Community." 61 A community may justly reserve property ownership to "those of their community," Locke insisted, and the reasonable explanation is that people whose property is protected by a commonwealth have more stake in fighting for it.

\footnotetext{
55. Michelle Maiese, Principles of Justice and Fairness, BEYOND INTRACTABILITY (July 2003, last updated July 2020), https://www.beyondintractability.org/essay/principles_of_justice [https://perma.cc/9SQF-3JMT].

56. See Prejudice in Iraq: Shiites, Sunni, and Kurds, ENCYCLOPEDIA.COM, https://www.encyclopedia.com/social-sciences/news-wires-white-papers-andbooks/prejudice-iraq-shiites-sunni-and-kurds [https://perma.cc/WME8-7USS] (July $10,2021)$.

57. The Federalist No. 2, at 6 (John Jay) (George W. Carey \& James McClellan eds., 2001).

58. See STAHL, supra note 4, at 27.

59. See THE FEDERALIST No. 2, supra note 57, at 5.

60. See STAHL, supra note 4, at 24.

61. LOCKE, supra note 32, at 346. For readers who cannot access the version of the Two Treatises cited here, the quote in the text comes from the Second Treatise, chapter VIII, section 117.
} 
Third, a liberal community needs to be communitarian in a few specific dimensions - most of all, in socializing citizens to have the social and political virtues expected in a system of republican government. Every political regime needs citizens to have character traits that contribute to the regime's overarching goals. As Michael Zuckert explains, even in a regime dedicated to natural rights, the government may establish and maintain "rights infrastructure'-the pattern of social institutions and characterological types that makes rights-securing possible." 62 The Virginia Constitution's Bill of Rights supplies a representative list of the character traits needed by a free people: " $[\mathrm{N}] \mathrm{o}$ free government, nor the blessings of liberty, can be preserved to any people, but by a firm adherence to justice, moderation, temperance, frugality, and virtue." 63

Fourth, people may be better able to exercise some of their natural rights if they use patriotism criteria to grant applications for citizenship. This possibility matters the most in relation to natural rights to engage in social activities. People cannot associate with one another without common ground rules, and in many cases, they need governments to establish those ground rules. But different peoples may rely on different ground rules for similar associations, and people in one community may reasonably demand that prospective citizens understand and respect the ground rules and goals they have set for associations in that community. Consider the application of the territory of Utah for United States statehood. Polygamy was widely practiced and tolerated in the territory of Utah. Congress barred the practice and barred Utah from becoming a state until it barred the practice. ${ }^{64}$ Congress prevented Utah and Utahans from associating with the citizens of the then-existing States on equal terms. Congress was motivated by a range of concerns: Citizens comfortable with polygamy would jeopardize poorer men's rights to marry, women's rights to be treated equally in marriage, children's rights to be raised in stable families, and the rights of all adults except male polygamists to associate politically as equals. ${ }^{65}$

62. MiChAEL P. ZUCKERT, LAUNCHING LiBERALISM: ON LOCKEAN POLITICAL PHILOSOPHY 283 (2002).

63. VA. CONST. art. I, $\S 15$.

64. See Reynolds v. United States, 98 U.S. 145, 164-66 (1878) (discussing the act codified at 12 Stat. 501 (1862)); see also Jessie L. Embry, Polygamy, UTAH HIST. ENCYC., https://www.uen.org/utah_history_encyclopedia/p/POLYGAMY.shtml [https://perma.cc/QW27-HJCM] (July 10, 2021) (reporting that Utah recently enacted a law reducing the penalty for polygamy from a felony to a misdemeanor).

65. Reynolds, 98 U.S. at 165. 
To be sure, if a political community follows a theory like the one just sketched, it relies on commitments that could be described as republican and nationalist. But those commitments get subordinated. They come to be part of the community's project to the extent that they run consistent with and help strengthen its most basic liberal commitments.

To avoid confusion, when a community strives both to secure rights and promote patriotism, the efforts to promote patriotic policies do not justify violations of the rights of outsiders. As Thomas West explains, natural rights obligate every people "not [to] harm foreigners' lives, liberty, or property. But when [a people] refuse[s] to admit foreigners to [its] community, [it] do[es] not treat them unjustly or deny them their rights. [It] simply leave[s] them in the same condition they were in before." 66 In other words, natural rights set baselines. Those baselines mark off standards of conduct that decent societies should not violate. Communities may structure their laws, policies, and social institutions to secure citizens' rights far more effectively than citizens could enjoy the rights outside those communities. But to that extent, communities generate benefits to their citizens. Patriotic communities may justly withhold those benefits from noncitizens, but they may not justly violate the rights of noncitizens.

\section{RECONSIDERING LOCAL CITIZENSHIP IN A GLOBALAGE}

Now, the last Part provided only a highly compressed sketch of the reasons why a theory of natural rights and liberalism might expect patriotism of its citizens, and why it might institute requirements for citizenship that evaluate applicants for citizenship by how patriotic they promise to be. But the sketch should make clear that patriotic liberal views are not crazy. Since they are not crazy, they have important ramifications for the argument in Local Citizenship in a Global Age. I want to close by considering that book's argument in light of the last Part's observations about patriotic liberal views - and also in light of Part IV's observations about the effects of cosmopolitan passions in politics. Again, as Part II explained, Local Citizenship in a Global Age makes it seem inevitable that globalization would overwhelm the control that state and national governments have

66. Thomas G. West, VindicAting The Founders: RACE, SEX, Class, AND JUSTICE IN THE ORIGINS OF AMERICA 158 (1997). 
exercised over immigration. Part IV and the last Part make that trend seem less inevitable.

Three implications go to the descriptive claims of Local Citizenship in a Global Age. First, assume that some citizens oppose open immigration and easy paths to citizenship. What motivates such citizens - liberal views, republican views, or ethno-nationalist views? The book strongly suggests that such citizens are in the grip of ethnonationalist views. At the outset, the book assumes: "Among the Americans who elected Donald Trump President, there is a seething anxiety over the perception that the meaning of citizenship is being diluted."67 In the book's three-model framework, only ethnonationalists can be the kinds of people in the grip of "seething anxiety." 68 But there is a possibility not considered: Maybe those citizens are liberals who think that republicanism, patriotism, and familiarity with important cultural traits all reinforce liberalism.

Now consider the citizens and political leaders who stand in opposition to the citizens who seem as seething and anxious. In Local Citizenship in a Global Age's three-part framework, the only factor that can explain why such citizens and leaders might support extending citizenship, the franchise, and public benefits is a commitment to liberalism. To be sure, many people do sincerely believe that people who are not United States citizens should be entitled to citizenship, the right to vote, and the benefits that states and the federal government extend to citizenship if they want to move here. Since the book suggests that citizens and leaders who oppose easy paths to citizenship are motivated primarily by ethno-nationalist views, by logic and fairness it really should have considered whether citizens and leaders who support broad access to citizenship are motivated primarily by cosmopolitan sentiments.

One last descriptive question. When municipalities make policies about citizenship, how influential are, on one hand, (what Stahl calls) republican and ethno-nationalist or (what I prefer to call) patriotic liberal views, and, on the other hand, liberal or cosmopolitan views? Local Citizenship in a Global Age reports that there is a "trajectory" and "pattern" in favor of expanding the franchise and its perquisites to

67. STAHL, supra note 4 , at 3 .

68. See id. at 7 (describing Trump voters as "hav[ing] turned a resentful eye toward cities"); id. at 8 ("backward-looking, place-bound, and racialized conception of citizenship"); id. at 17 ("quasi-nationalist xenophobia, in which outsiders are ostracized and scapegoated"). 
noncitizens. ${ }^{69}$ Is the trend that pronounced? In the book's report, the franchise has been extended by the state of New York (in school board elections, until elected school boards were abolished), the city of Detroit, and ten Maryland municipalities; municipalities in Maryland, Vermont, and Massachusetts have at least debated extending the franchise. ${ }^{70}$ In my view, those extensions are not widespread enough to say that there is a clear and unshakeable consensus for expanding the franchise. I interpret the same facts as follows: Some municipalities support federal immigration policies, many more say little about those policies (probably because they think they have little to add), and a small number of municipalities go in a different direction - in states that tend to be progressive in national politics and cosmopolitan in their outlooks.

The concerns I am expressing here have normative implications as well. Again, one of the two main lessons of Local Citizenship in a Global Age is that local governments can and sometimes should set citizenship policies different from the ones set by state or federal governments. $^{71}$ Part III studies three different conceptions of citizenship that municipalities might try to promote - if globalization creates new challenges that the state and national governments are incompetent to address, and if the liberal conception seems too "thin [a] gruel" for municipalities to promote. ${ }^{72}$ In Parts IV and VI, though, I identified two considerations that militate in favor of limiting municipal policy-making on citizenship. As Part VI explained, citizens in any community have strong interests in being assured that fellow citizens are loyal to their common political project and wellsocialized enough to respect important institutions like marriage, contract, and political processes. In a federal system, central governments are better positioned than municipal governments are to factor in the effects of policies on common culture; in the United States, that difference favors limiting municipal control over immigration policy and keeping such control in the hands of the states or the federal government. ${ }^{73}$

Separately, Local Citizenship in a Global Age suggests that state and federal policies often rely too much on the ethno-nationalist model, and it also suggests that municipal governments can counteract

69. Id. at 14 .

70. See id. at 2-3 n.6.

71. Id.

72. Id. at 10 .

73. Id. at 48-49. 
these tendencies. ${ }^{74}$ Fair enough. Since every government can make mistakes, however, a full account of citizenship federalism needs to anticipate that municipal governments might make mistakes when they institute policies affecting citizenship. As Part IV showed, people can get caught up not only in desires to be surrounded only by people of similar races or nationalities but also in cosmopolitan desires to downplay traits and habits that distinguish particular peoples. That possibility needs to be considered in a full account of citizenship federalism, and it is not in Local Citizenship in a Global Age.

Finally, the concerns that motivate opponents of broad citizenship and easy immigration seem more serious than they seem in Local Citizenship in a Global Age. Opponents may not necessarily be motivated by desires to exclude people of different races or nationalities. Instead, opponents may believe sincerely that a free people cannot govern itself unless its members have the traits that Part VI associated with patriotism. Concerns like those would justify citizenship policies that require proof that new citizens understand important aspects of American government and social life. They also justify withholding from people who are not citizens public benefitsaccess to property, public education, and public health care-intended primarily for fellow citizens. Now, these concerns might be overwrought, or such concerns might not justify the citizenship and welfare policies now in effect in federal or state law. But the concerns are serious and durable. Because Local Citizenship in a Global Age hastens to study new forms of local citizenship, it passes hastily over these concerns.

74. See, e.g., id. at 83. 